\title{
Measuring the Cost of Privacy: A Look at the Distributional Effects of Private Bargaining
}

\author{
JEFFREY KUCIK AND KRZYSZTOF J. PELC**
}

\begin{abstract}
Transparency is one of the most contested aspects of international organizations. While observers frequently call for greater oversight of policy making, evidence suggests that settlement between states is more likely when negotiations are conducted behind closed doors. The World Trade Organization's (WTO) legal body provides a useful illustration of these competing perspectives. As in many courts, WTO dispute settlement is designed explicitly to facilitate settlement through private consultations. However, this study argues that the privacy of negotiations creates opportunities for states to strike deals that disadvantage others. Looking at product-level trade flows from all disputes between 1995 and 2011, it finds that private (early) settlements lead to discriminatory trade outcomes - complainant countries gain disproportionately more than the rest of the membership. When the facts of a case are made known through a ruling, these disproportional gains disappear entirely. The article also finds that third-party participation - commonly criticized for making settlement less likely - significantly reduces disparities in post-dispute trade. It then draws parallels to domestic law and concludes with a set of policy prescriptions.
\end{abstract}

How much transparency should there be in global governance? While public opinion is quick to call for greater openness in international institutions, political scientists remain ambivalent. Recent findings show that when bargaining is conducted in public view, negotiators are vulnerable to influence by powerful domestic interests. These domestic pressures create incentives to adopt more aggressive stances, which significantly reduce the prospects for compromise between parties. ${ }^{1}$ As a result, bargaining may be more productive behind closed doors, shielded from the view of hardline interests. The supposed relationship between privacy and effectiveness explains why countries frequently conduct diplomacy and international bargaining in private. ${ }^{2}$

The benefits of low transparency are evident in various international institutional settings. For example, privacy allows governments to shift blame to international institutions like the European Union (EU) and the International Monetary Fund (IMF), reducing the political fallout over painful economic reforms, and making these reforms more likely. ${ }^{3}$ For example, greater transparency in international financial institutions reduces the effect of such interventions. In addition, despite considerable pressure for change, there is evidence that investment disputes including those that proceed under the World Bank's International Centre for the Settlement of

\footnotetext{
* Department of Political Science, City College of New York (email: jkucik@ ccny.cuny.edu); Department of Political Science, McGill University (email: kj.pelc@mcgill.ca). We thank Marc L. Busch, Stephen Chaudoin, and the participants of the European Consortium of Political Research Joint Sessions of Workshops 2012, the University of Copenhagen in June 2013, the University of Warsaw in September 2013 and the International Political Economy Society 2013 annual meeting for useful comments. All remaining errors are our own. We thank Yanick Touchette, Casey McDermott and Eliza Wood for excellent research assistance. Data replication sets and online appendices are available at http://dx.doi.org/doi:10.1017/S0007123414000520.

1 Busch and Reinhardt 2006; Fox 2007; Kahler 2004; Stasavage 2004a, 2004b.

2 Kurizaki 2007; Leventoglu and Tarar 2005.

3 Kahler 2004; Vaubel 1986; Vreeland 2003.
} 
Investment Disputes (ICSID), where governments have strong incentives to manage audience costs - have remained stubbornly private. ${ }^{4}$

There is a danger, however, to taking these claims too far and losing sight of privacy's welfare costs. Although privacy insulates negotiators from certain political pressures, it also disenfranchises some actors affected by 'closed door' deals. This is precisely why private deliberations within international institutions have become a frequent target of criticism, often portrayed as 'remote, secretive, unintelligible, and unaccountable'. Thus there is an important tension within institutions: privacy promotes settlement, but it also increases the risk that settlement comes at a cost - namely, the interests of other countries.

There have been significant theoretical advances in this debate, yet empirical studies continue to lag behind. This is not surprising; the nature of private negotiations makes them difficult to study. If affected actors cannot scrutinize private deals, how might scholars do better? We confront this challenge by looking to an institution in which privacy plays an important, observable role: the World Trade Organization. The WTO's legal body, praised as the 'cornerstone of the trade regime', features a fortuitous design that pits both sides of the transparency argument against one another.

The rules of the global trade regime enshrine the principle that privacy encourages agreement. The WTO's Dispute Settlement Understanding (DSU) is explicitly designed to promote outof-court settlement, requiring that states consult with each other before a panel is convened. Crucially, this mandatory consultative process, and its results, remain private - the exact terms of 'early settlements' are rarely revealed to the larger membership. In this way, the DSU's design is a testament to the belief that some measure of privacy facilitates settlement.

In this article, we take a closer look at the potential downside of private consultations. We argue that privacy creates opportunities for states to strike what appear to be discriminatory deals. 'Discrimination' occurs when settlements disproportionately favor litigants, at the expense of the larger membership. In the context of trade, discrimination happens when the trade benefits following a settlement are distributed unevenly across WTO members with a stake in the matter. This is not merely a theoretical possibility; the WTO is aware that discrimination can occur. WTO training modules speak of 'the danger that the parties to a dispute might be tempted to settle on terms that are detrimental to a third Member not involved in the dispute'. ${ }^{6}$ In addition, the WTO's core principles are designed to prohibit precisely this kind of discrimination.

Crucially, the terms of agreements cannot be observed easily under private settlement. This opacity makes enforcing rules and norms difficult. Privacy therefore skews deals in favor of the parties in the room. The observable implication is that we expect to see that early settlements are, on average, discriminatory - that is, they result in trade outcomes that disadvantage states not party to the consultative process. To be sure, we do not argue that the previously lauded benefits of privacy are any less real. Privacy does render settlement more likely. However, our findings demonstrate that the net benefits of early settlement cannot be understood without a fuller account of its asymmetric distributional consequences.

Our article also explores the institutional features that reduce the likelihood of discrimination. Recognizing the possible risks associated with privacy, the WTO introduced 'third-party' status, which allows non-litigants to enter the room during the otherwise private consultative process. A number of scholars have seized upon this reform to explore one side of the transparency debate. Davey and Porges warn that third parties make settlement more difficult by

4 Hafner-Burton et al. 2013.

5 From Schmitter's $(2003,83)$ characterization of Europeans' fears over the EU's lack of transparency.

6 WTO 2004. 
increasing transparency. ${ }^{7}$ Busch and Reinhardt bolster this claim by showing that the odds of settlement drop by more than half, on average, when a dispute features third parties. ${ }^{8}$ Their explanation is that the presence of third parties induces litigants to look tough, reducing the likelihood of compromise.

We do not dispute these claims. Rather, we argue that the presence of third parties can also be used to examine the other, less empirically validated, side of the transparency debate. We expect that when third parties are in the room, litigants grow more likely to reach solutions that are beneficial to the broader membership. In other words, third parties act as unwitting enforcers of the principle of non-discrimination.

We present systematic evidence of the average effects of privacy in WTO disputes. We examine trade flows in the wake of all WTO disputes since 1995 that concern merchandise trade. The results provide strong evidence of discrimination after early settlement. When agreements are reached under private consultations, complainants benefit significantly more than the rest of the WTO membership. Importantly, these findings are not simply a result of complainants having more to gain. Even when taking into account the precise nature of disputes, including whether they concern primarily bilateral issues, there are large differences in the trade benefits accrued by complainants relative to the members. As such, our findings should be cause for concern to observers who view the privacy of consultations as strictly welfare enhancing.

This article provides what is, to our knowledge, the first evidence of discriminatory settlements at the WTO. Yet our findings also bring good news. We show that by their sheer presence, third parties significantly reduce the disparities in trade, extending concessions to the remainder of the membership. Moreover, this enforcement effect holds when we account for the existing literature's claim that third parties make settlement less likely. By implication, early settlements can be thought of as a public good, but only when they are conducted in a sufficiently open manner.

Our results demonstrate that transparency has important consequences for states in international institutions. The distribution of trade benefits among WTO members is shaped by the privacy of the dispute settlement process. Even in an institution built on the principles of reciprocity and non-discrimination, states take advantage of the opportunities that privacy creates to strike deals that violate these norms.

We are not the first to examine distributional effects in the trade regime. When some states gain more than others, scholars often cite power asymmetries. In the case of the WTO, Gowa and Kim argue that a select club of wealthy countries captures the gains from membership because of the way GATT negotiations favored large markets. ${ }^{9}$ Subramanian and Wei present a similar finding, showing that industrial countries gain the most from the WTO. ${ }^{10}$ By analogy, power may be playing a role in our setting - namely, powerful countries might collude to resolve a disagreement and impose the outcome on others. This implication is testable, and in the analysis we ensure that our story is not reducible to power in this fashion. Our argument focuses on the institution itself. In fact, the effect we are interested in is more pernicious than inequities produced by power politics, since what drives discrimination is a set of rules widely seen as being in the interest of the institution. Thus our effort is more akin to the work of Steinberg, who claims that a by-product of the consensus decision-making rule, which also

\footnotetext{
7 Davey and Porges 1998.

${ }^{8}$ Busch and Reinhardt 2006.

9 Gowa and Kim 2005; Kim 2010.

10 Subramanian and Wei 2007.
} 
enjoys widespread support, is that it facilitates agenda setting by rich countries. ${ }^{11}$ In a similar vein, we identify an overlooked drawback to a set of rules that enjoys wide support both within the institution and among scholars.

We close with a set of policy prescriptions. The WTO proscribes unfair settlements, yet its institutional design makes enforcement difficult. As we show, the principal problem lies not in the privacy of the negotiations themselves, but in the opacity of the outcome of those negotiations. We compare the lack of oversight of these negotiation outcomes with another domestic-level issue area: antitrust legislation. We use this setting to describe how an oversight mechanism might function in the trade regime, and argue that it would come at comparatively little cost to the effectiveness of negotiations.

\section{ARGUMENT}

The opacity of international governance is not, as the popular view sometimes has it, the result of international institutions gone astray, or of institutions 'taking on a life of their own'. Rather, the low levels of transparency often built into institutions - just like the designs of voting rules and flexibility clauses - are the result of deliberate political decisions. Governments design institutions in a way that recognizes a shared interest in a certain degree of privacy.

It is no exaggeration to say that privacy is at the core of global governance. Governments delegate power to international institutions in an attempt to insulate themselves from domestic interests opposed to reform. Governments have incentives to do so, because domestic interests can block political outcomes that stand to benefit the median voter. ${ }^{12}$ In this way, delegation to international institutions is a means of avoiding interference from such domestic interests. Whether in trade or monetary affairs, or even legislative politics, delegation invariably functions through some measure of opacity.

In the context of international negotiations, keeping powerful domestic interests outside of the room is key to producing a cooperative outcome that is welfare enhancing. Open negotiations, by contrast, make it less likely that the parties can compromise. The presence of hard-line domestic actors, or other governments, incentivizes negotiators to adopt more aggressive, less cooperative postures. Negotiators try to appear 'tough' in order to appease a domestic constituency, or to invest in their negotiating reputation for the sake of third countries, at the expense of compromise.

The view of privacy as key to agreement is equally evident in the domestic arena, in spite of the commonly held belief that domestic settings feature more accountability. Congressional committees meet in camera before submitting the achieved bargain to the remainder of the legislature for approval. Thus at both the international and domestic levels, there exists a widespread belief among policy makers and scholars that privacy makes (beneficial) agreement more likely. ${ }^{13}$

Privacy also achieves a second, related goal. Simply put, bargaining in public grows intractable as a greater number of parties with heterogeneous preferences are allowed to influence the outcome. ${ }^{14}$ In the memorable words of the American diplomat Harlan Cleveland, the question is, 'how do you get everyone into the action and still get action'? ${ }^{15}$ Privacy may be a means of reducing the number of voices and the diversity of interests that need to be reconciled.

${ }^{11}$ Steinberg 2002.

${ }^{12}$ McGillivray 2000.

13 As Martin and Simmons $(1998,742)$ assert, 'The analogy between politicians deciding to delegate authority to bureaucrats or committees and states delegating authority to international institutions is strong'.

${ }^{14}$ This has arguably been the fate of the Doha Round.

${ }^{15}$ Keohane and Nye 2001. 
Despite these arguments, the welfare-enhancing effects of privacy come with significant caveats. The private nature of international institutions has come under fire from critics who denounce low transparency as indicative of a 'democratic deficit' and a lack of accountability. Stasavage points out that the European Council of Ministers faced heavy criticism for the relatively secretive nature of its decision-making process. ${ }^{16}$ Similarly, private negotiations with the IMF previously allowed governments to blame painful reforms on the institution. Yet in response to protests, the IMF itself began insisting on greater transparency in its dealings with governments, often against the latter's wishes. ${ }^{17}$ The 'club model' of international governance, in which a small group of countries negotiates package deals in private and presents the outcome for the approval of the remainder of the membership, ${ }^{18}$ has been roundly denounced, and largely abandoned.

How to best characterize the dangers of privacy? Its critics argue that deals struck behind closed doors are likely to advantage some actors at the expense of others. Note that this concern echoes the arguments in favor of privacy. Private negotiations increase the likelihood that negotiated outcomes are achieved in spite of opposition from special interests. Yet privacy also increases the chance that deals made behind closed doors systematically disadvantage those not in the room. Put another way, privacy favors agreement, whereas publicity favors the equity of those agreements. The question is how to recognize the point at which the costs of privacy outweigh its gains for cooperation.

This article investigates one side of that trade-off by attempting to measure the costs of privacy. We do not argue against the notion that privacy increases the odds of agreement. Indeed, we weave this insight into our empirical analysis. We argue, instead, that low levels of transparency in international organizations create opportunities for members to discriminate against one another, in a way that can jeopardize an institution's own objectives. When institutions protect the privacy of bargaining, they make it more likely that those bargains will be reached, but do so at the cost of equity. Simply put, settlement may come at the expense of broader cooperation.

Given the nature of private bargaining, it is hard to evaluate the trade-offs underlying this debate with any precision. The only negotiations we can observe are those that were made public for a reason. One setting that provides a fitting laboratory for this task is the WTO, an institution that has been at the center of the debate over transparency and democratic deficits. ${ }^{19}$ Unlike many other institutional settings, the WTO allows us to directly observe the outcome of private settlements, by measuring subsequent trade flows between members. ${ }^{20}$ Some of these negotiations are entirely insulated from interested parties, while others are more open. Our research design exploits this unique variation. In all instances, the complainant and the defendant have reasons to collude over a settlement, at the expense of those countries not in the room. Privacy creates a space in which this kind of discrimination can take place. We seek to measure the average cost of privacy by looking to the WTO and asking: does privacy affect the distribution of the gains in the wake of disputes?

\section{Encouraging Private Settlement over Public Rulings}

In WTO trade disputes, as in other legal settings, there are good reasons why countries prefer to settle early, rather than litigate. The main reason is that the result of litigation is made public,

${ }^{16}$ Stasavage 2004a.

17 Kahler 2004.

${ }^{18}$ Keohane and Nye 2001.

19 Kahler 2004; McGillivray 2000.

${ }^{20}$ This is akin to estimating the content of private monetary settlements in civil suits by monitoring all parties' bank accounts. 
while negotiated settlements remain private. Litigation formally denounces a government's behavior as a breach of its obligations; governments are naturally interested in avoiding such public condemnation. From the standpoint of domestic politics, these verdicts constitute the 'fire alarm' that alerts constituents to occasions when governments violate their obligations. ${ }^{21}$ Settlements that are struck behind closed doors (the details of which are not made public) avoid the sounding of the fire alarm, and the resulting audience costs.

To be sure, governments join agreements precisely because of their inclusion of such fire alarms, which increase the costs of violations and bolster the credibility of their promises to liberalize. ${ }^{22}$ Yet once they are members of a trade agreement, governments are eager to avoid being branded as violators. Private settlement provides a means of resolving disagreements without tripping the fire alarm of an unfavorable legal verdict. In other words, private settlements greatly reduce the defendant's audience costs, which favors both parties. ${ }^{23}$ This efficiency comes from the way in which privacy avoids the political fallout to the defendant of giving in to a foreign country's demands. The willingness to avoid these audience costs, especially on the part of the defendant, can be sufficient to motivate agreement. ${ }^{24}$ Just as importantly, a commitment to privacy avoids an escalation of public demands that cannot be satisfied. ${ }^{25}$

An additional motive for settling early is to avoid high litigation costs. Going to court consumes legal and bureaucratic resources, a real concern for all but the wealthiest of countries. Litigation, in other words, much like war, is an inefficient means of resolving disagreements. To avoid these costs, countries should be willing to concede more to prevent the case from going to trial. ${ }^{26}$ In sum, governments are keenly aware of the political and financial costs of litigation and adverse WTO rulings, and behave strategically to avoid them.

These incentives help explain the high rate of early settlement at the WTO: 63 per cent of disputes never make it to a panel ruling. Of these, about half end with a 'mutually agreed solution'; the remainder are dropped by the complainant. This is not happenstance; the preference for settlement over litigation is built into the institution's design. The DSU explicitly mentions in Article 3.4 that any rulings or recommendations 'shall be aimed at achieving a satisfactory settlement of the matter'. Successful courts cannot wait until litigation to exert their primary impact.

To increase the odds of settlement, the WTO's institutional design not only imposes a period of mandatory bargaining in advance of litigation; it actively protects the privacy of this bargaining phase. Indeed, while the institution has progressively increased its overall level of transparency in recent decades, the privacy of consultations has been jealously guarded - with the notable exception of third parties, which we examine closely below. The privacy of consultations is geared toward allowing litigants to settle their differences without the intrusion of domestic groups or other countries with interests at stake. It keeps governments from having to posture for the sake of their industries or trade partners. If these actors were in the room, litigants might have an incentive to 'act tough', reducing the odds of agreement. ${ }^{27}$ As Keohane

21 Chaudoin 2014; McCubbins and Schwartz 1984; Sevilla 1997.

22 Maggi and Rodríguez-Clare 1998; Mansfield, Milner, and Rosendorff 2002; Staiger and Tabellini 1987. 1999.

23 Kurizaki 2007, 555.

24 Kurizaki 2007.

25 Leventoglu and Tarar 2005.

26 Gilligan, Johns, and Rosendorff 2010.

27 Busch and Reinhardt 2006. 
and Nye put it, 'consummating deals may often require a certain degree of obfuscation of the tradeoffs being made'. ${ }^{28}$

\section{The Impact of Privacy on the Content of Settlements}

Settlements as public goods. The WTO's rules clearly intend for all members to gain from settlements. Its central principle, most-favored nation (MFN), states that any concession granted to one member shall be granted to all members. Dispute settlement is usually a bilateral process; in most cases, a single complainant challenges the policy of the defendant country. Yet crucially, regardless of the number of participants, it features the same MFN obligation to extend all bilateral concessions to the membership as a whole. This obligation is contained in DSU Article 3.5 , which outlines that any solutions arrived at during dispute settlement must be consistent with the agreement, meaning that the settlements reached between litigants cannot be discriminatory. A defendant cannot legally lift barriers on a given product for the complainant without also lifting barriers on that product for all other members, and it cannot replace one violation with another.

One implication is that, under MFN, non-participants can free-ride on bilateral negotiations, including those conducted during a dispute. ${ }^{29}$ Anecdotal evidence supports this claim. ${ }^{30}$ When the United States challenged Japan over import restrictions on apples in 2003, New Zealand, which also exports apples to Japan, stood to benefit in equal measure. As the chairman of Pipfruit New Zealand Growers rejoiced, '[t]he Americans will now sit down to negotiate a protocol with the Japanese and we will hope to piggy-back on that'. ${ }^{31}$ US apple exporters were the ones to successfully lobby for a dispute. Yet Pipfruit and other apple exporters to Japan stood to gain as much as US exporters. This is the public goods promise of dispute settlement.

However, the multilateral and bilateral facets of the WTO sometimes conflict with each other, as during early settlements. The means by which the institution promotes early settlement private consultation - also makes dispute settlement more prone to discriminatory deals. As a result, there is a clash between the way in which the institution seeks to increase the size of the pie and the means by which it would ensure its equitable distribution.

Settlements as private benefits. Countries have straightforward incentives related to dispute settlement. Complainants want greater market access, which they consider to be unfairly restricted. Defendants would rather concede as little as possible in order to continue protecting the industry that successfully petitioned for protection in the first place. Ultimately, whatever concessions the defendant is forced to make, it would prefer to concentrate them on the complainant, rather than extend them to the membership at large. The incentive to collude in this way, and the way in which privacy facilitates such collusion, means that private settlements make discrimination more likely. An analogous concern crops up in a host of issue areas, from antitrust litigation in the domestic realm to investment disputes in the ICSID. In the latter case, as Hafner-Burton et al. warn, 'secrecy prevents public scrutiny of arbitrator conduct or conclusions, which raises concerns about discrimination'. ${ }^{32}$

Opportunities for discrimination are high in the case of trade. Davis provides a useful example relating to Japanese concessions over beef imports to the United States under

${ }^{28}$ Keohane and Nye 2001, 17.

${ }^{29}$ Bown 2005, 2009.

30 Johns and Pelc 2013.

31 'Apple Growers Reject WTO Ruling', Sydney Morning Herald, 27 November 2003. Available from http:// www.smh.com.au/articles/2003/11/27/1069825915658.html.

${ }^{32}$ Hafner-Burton et al. 2013. 
GATT negotiations. ${ }^{33}$ The Japanese knew they would have to give in to US bilateral pressure; they preferred to allocate all their market opening to this one powerful partner rather than open up the market to global competition. Davis quotes a former official, 'If we had to accept the intrusion of beef imports, the goal was to give maximum satisfaction to the United States' ${ }^{34}$ So the Japanese created a special category of beef that only the United States exported, liberalized imports on this category and left barriers untouched on all other types of beef. This possibility of tailoring concessions to the needs of the complainant, in a way that minimizes overall market opening, is the reason why both parties are attracted to discriminatory settlements under private bargaining. ${ }^{35}$

Discriminatory settlements, which are struck between litigants at the expense of the greater membership, can take on many forms. Creating new product categories ranks as the most obvious among these. ${ }^{36}$ Unilaterally redefining product categories is an actionable violation if it harms members that have not agreed to the change, or if it violates a country's WTO commitments. At the other end of the spectrum, the least detectable would be side payments, such as concessions on other products. ${ }^{37}$ In addition, note that discrimination need not be strictly illegal for it to nullify or impair the interests of non-participants by diverting trade. For instance, the defendant may switch to a quality standard that the complainant's firms already meet because of their similarity to the complainant's own domestic standards, an effect our analysis is designed to pick up. Changing regulatory standards is not necessarily illegal, but such settlements would raise objections from affected countries if they were in the room, since these changes may disadvantage trade partners based on their abilities to meet those standards. Some modifications of national standards can be legally challenged, yet affected countries that are not in the room have little chance of challenging a settlement of which they are unaware.

Evidence from interviews provides support for countries' incentives, as well as their fears surrounding private settlement. One official from Japan's WTO Compliance and Dispute Settlement Division claimed that one of the main reasons for Japan's participation in a dispute as a third party is to prevent discrimination. ${ }^{38}$ They were concerned that during private consultations, litigants 'may not offer to others the same favor they offer the other party'.39

Since it is difficult to know what is driving other countries' trade flows, interviewed officials explained that some discriminatory deals reached in private are nearly impossible to detect. ${ }^{40}$ Discrimination is difficult to discern, since countries left out of a deal may see little change in the treatment they receive at the border. All a negatively affected industry might observe is a change in price, without any means of knowing whether the change is due to a concession

33 Davis 2003.

34 Davis 2003, 152.

35 Maggi and Staiger 2008, 40.

36 Indeed, when such 'tariff reclassifications' occur, they are often legally challenged, usually as violations of GATT Article II. In this way, in 2005, Mexico alleged that Panama discriminated against it by reclassifying milk into two categories, one for 'baby formula', on which it reduced all tariffs to 0 per cent, and another for all other milk products, for which it raised the tariff rate from 5 to 65 per cent. The parties settled, with Panama reducing the tariff on 'other' milk products back to 5 per cent, as Mexico demanded (WTO document WT/DS329/2).

37 We do not purport to pick up such side-payments in our analysis, given our focus on trade in the products at issue. Consequently, our analysis can be thought to be conservative in this respect; there is likely to be more discrimination than we can identify by examining disputed products.

38 Authors' interview with Ministry of Economy, Trade and Industry (METI) official, Tokyo, 20 November 2013.

39 Authors' interview with METI official.

40 Authors' interview with METI official. 
tailored to the interests of other countries or the result of, for example, a shift in demand. Legal scholars concur with the difficulty of detecting discrimination: 'as the content of the mutually satisfactory solution is not disclosed, there is a small chance for an interested third Member to detect it and take action against it under the WTO DSM' ${ }^{41}$

Yet discrimination is sometimes detected and denounced. Bown describes how the GATT Bananas dispute resulted in a settlement, the Framework Agreement on Bananas, which favored African, Caribbean and Pacific countries at the cost of other banana exporters. ${ }^{42}$ The United States went on to challenge this settlement as discriminatory through both legal and extra-legal means. In an equally high-profile case, when the United States and the EC finally reached an agreement in EC-Hormones, others warned that the settlement was discriminatory in a way that violated DSU Article 3.5. Indeed, the settlement could be taken to define 'high-quality beef', on which a larger quota was offered, as 'only that of the type exported by the US'. ${ }^{43}$ As a representative from Uruguay, an important beef exporter, put it: 'There was no justification for maintaining that this specific type of beef, which received preferential treatment, was different from other high quality beef. This constituted discriminatory treatment in favour of a certain origin'. ${ }^{44}$ The representative of Uruguay went on to read Article 3.5 of the DSU in its entirety, stressing that any settlement reached in the case should not be struck at the expense of third countries. In a smaller dispute brought by Korea against Japanese restrictions on seaweed imports, Japan-Laver, Japan agreed to effectively allocate its quota of dried and seasoned laver imports exclusively to Korea. ${ }^{45}$

Why were these discriminatory agreements made known? Because they were reached after a ruling was circulated, rather than during private pre-trial consultations. As we demonstrate below, once a panel ruling is circulated, expectations regarding the content of an eventual agreement converge. As a result, discrimination grows less likely. When it does take place, it is often challenged or criticized, as in the cases of Bananas, Hormones and Laver. Given what we know of countries' incentives, how both litigants have an interest in collusion and how such collusion grows more likely under privacy, theory suggests that these observable cases are only the tip of the iceberg.

\section{Information Provision before vs. after a Ruling}

Our argument focuses on the limited amount of information released during private consultations vs. the full disclosure of terms once a ruling has been circulated. As we have stressed, this variation is not coincidental; it is part of the institution's design, a means of sheltering negotiations in the shadow of the law to increase settlement rates and avoid inefficient litigation.

We know discrimination does occur, as one can see in the aforementioned examples of questionable agreements struck even after a public ruling has been circulated. We also know that such objections are never voiced in reaction to mutually agreed solutions reached prior to a panel ruling, since there is insufficient information available about these early settlements. The institution is never even formally notified of some early settlements, as noted above. ${ }^{46}$

41 Nakagawa 2007, 858.

42 Bown 2009.

43 WTO document WT/DSB/M/270.

44 Statement by the Representative of Uruguay, 19 June 2009, WTO document WT/DSB/M/270, para 68.

45 The settlement read: 'An annual import quota will be allocated exclusively for Korean Laver Products' (WT/DS323/5, see Alschner 2012). Observers were quick to denounce this agreement as discriminating against other members to the benefit of the parties in the room (Nakagawa 2007).

46 See WTO document WT/DSB/M/15. 


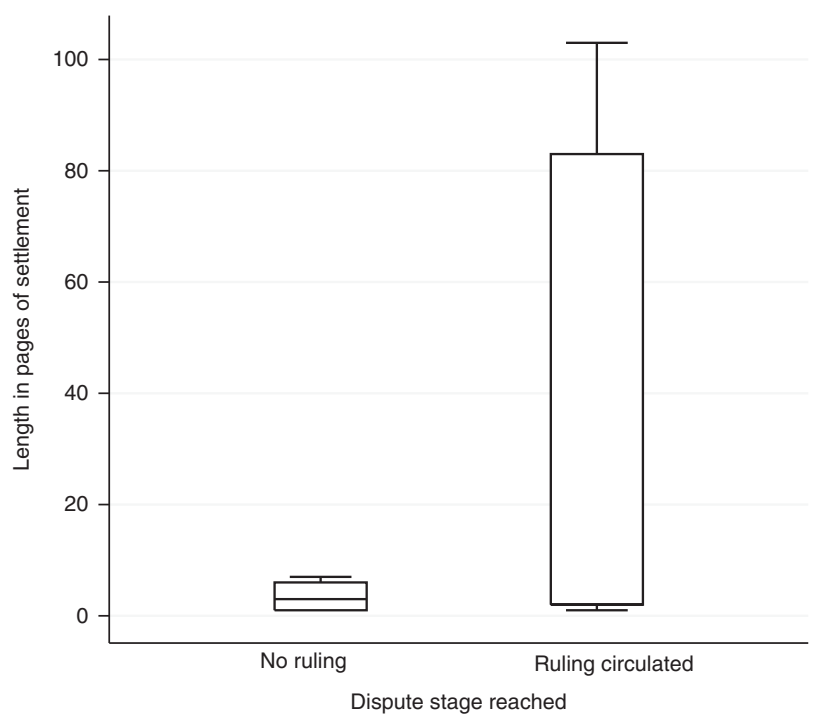

Fig. 1. Average length of settlement, by dispute stage reached

Settlements that led to verdicts and appeals, by comparison, largely take place in public view. Panel rulings, which run in the hundreds of pages, publicize the facts of the case, as well as the stakes and arguments of all parties. They converge the membership's expectations about what might constitute a satisfactory outcome.

This wide informational disparity between cases that settle early and those that reach a ruling may be difficult to understand. After all, one of the WTO's core missions (and that of other international institutions) is the distribution of information about its members' trade policies. To briefly illustrate the difference that the ruling makes for the amount of public information available about a case, we compare the length of all notifications of settlements reached before and after a ruling. This is a crude measure, yet it remains a telling one for the purpose of illustration.

Our premise is that when settlements are reached past the ruling stage, they have largely lost their private nature. To demonstrate this, we collect all ninety-one notifications of a mutually agreed solution: of these, thirty-two were concluded after the ruling, and fifty-nine were concluded without a ruling having been reached. These settlements do not include deals that were not notified, such as the entirely private deal concluded between Malaysia and Singapore in 1996, when the dispute was dropped by Singapore before ever reaching a verdict. In that instance, only years later was it made clear that a bilateral arrangement had been reached. ${ }^{47}$

The difference in the detail provided in pre-ruling vs post-ruling deals is made apparent in Figure 1. The average length of the notification of a settlement is nine pages when reached prior to a ruling, and twenty-eight pages when reached after a ruling. This difference is highly statistically significant. All these documents have the same legal status and are constrained by

47 '[The Chairman] recalled that in July 1995, following Singapore's withdrawal of its request for consultations with Malaysia, the Chairman of the DSB had stated that: "it was important that at this stage when DSB practices were being established that Members considered the need to register formally not only the initiation of disputes but also the settlement and resolution thereof'. This precedent had not been followed' (emphasis added). Visibly, the precedent has fared no better since this dispute (Dispute Settlement Body, 24 April 1996, WTO Doc WT/DSB/M/15). 
the same requirements for openness. Yet when deals are reached prior to a ruling, and the entire case has taken place in a closed room, countries are far less likely to provide details about the content of their settlement. Indeed, that is why countries prefer early settlements in the first place. Some notifications of early settlements amount to one sentence: 'On behalf of our authorities we would like to inform you that Hungary and Croatia did find a mutually satisfactory solution to this case in 2003. ${ }^{48}$ In such cases, members outside the room have no chance to scrutinize the content of the bilateral deal.

Ultimately, cases like Bananas, Hormones and Laver, where one can identify discrimination because a deal is reached after a panel has clarified the facts of the case, are likely to be the tip of the iceberg. While the publicity produced by a ruling - which converges members' expectations about what a settlement should look like - acts as a deterrent to discrimination, no equivalent deterrent exists for cases that settle in private, since challenges become downright improbable. ${ }^{49}$ In sum, discrimination is likely to be concentrated in early, private settlements.

If the WTO's institutional design favors increasing the size of the pie at the expense of its fair distribution, this should be observable in the distributional consequences of disputes on individual countries' trade flows. This reasoning leads us to the following hypothesis. If private consultations are conducive to discriminatory settlements, then:

HYPOTHESIS 1: The complainant will capture a greater portion of the gains from a WTO dispute under privacy than under publicity.

As we demonstrate above, we can test this hypothesis by examining the distribution of benefits from trade under early settlements, the terms of which are kept private, and comparing it to the distribution of benefits under agreements reached once a ruling has been circulated and the facts of the case are made public.

Exploiting the variation in the stage disputes reach has several benefits, which we develop further in the discussion of the research design. Chiefly, it gets us around the possibility that some dispute characteristics, rather than privacy vs. publicity, are driving the distribution of benefits we observe. As long as dispute characteristics are not correlated with the expected stage a dispute reaches, such dispute-specific traits will have no bearing on our results.

Our first hypothesis echoes a similar argument in the realm of domestic politics, where the trade-off between equity (provided by greater transparency) and effectiveness (which hinges on privacy) has been studied most closely. And it has generated identical concerns, despite the common perception that the domestic sphere is more transparent and less afflicted with a 'democratic deficit'. ${ }^{50}$ While these studies lack the benefit of the rich data available for the international trade regime, domestic legal observers have long warned that the option of settling behind closed doors "works in favor of "private peace" and in opposition to "public justice", 51 In a noted critique, the philosopher David Luban claimed that settlements in domestic law lead to an 'erosion of the public realm'. 52

Even in the domestic realm, then, informational gaps are thought to have distributional consequences. By contrast, the WTO has no opportunity for judicial oversight of private early settlements, an institutional lacuna we come back to in our conclusion. Little wonder, then, that some WTO observers have expressed concerns that 'settlements may be struck at the expense of

48 WTO Document WT/DS297/2. See Alschner 2012.

49 Nakagawa 2007.

50 Moravcsik 2004.

51 Menkel-Meadow 1995.

52 Luban 1994. 
third parties or may remain unknown to the larger public'. ${ }^{53}$ Next, we attempt to measure this likelihood, and quantify the cost of privacy in international trade settlements.

\section{The Effect of Third Parties on the Distributional Consequences of Early Settlements}

The designers of the WTO were manifestly aware of the possibility of clashes between bilateralism and multilateralism. In Bagwell and Staiger's telling, it is precisely to prevent 'bilateral opportunism' that the WTO elevates the principles of reciprocity and nondiscrimination, and allows for non-violation complaints. ${ }^{54}$ Yet Bagwell and Staiger recognize that these rules form only a 'first line of defense' against bilateral opportunism. ${ }^{55}$ Indeed, this line of defense may be insufficient to prevent violations of the regime's core principles.

One feature of dispute settlement that may have a countervailing impact is the presence of third parties. Third parties are member states other than the litigants, which can be present during a dispute as early as the period of consultations if they claim an interest in the trade at stake, or in the systemic implications of the dispute. Third-party status has recently received much attention in the literature. On the one hand, we know third parties gain from participation in terms of trade flows, ${ }^{56}$ and we know third-party status allows developing countries to acquire legal capacity. ${ }^{57}$ On the other hand, and in keeping with the trade-off identified above, it has also led to backlash from observers who claim that third parties decrease the likelihood of settlement, and thus increase the risk of litigation. ${ }^{58}$ This scholarship has demonstrated that the presence of third parties has a significant impact on the outcome of negotiations. Third parties decrease the odds of settlement; as few as five third parties appear to render a mutually agreeable solution all but impossible. ${ }^{59}$

We do not contest these findings; indeed, our analysis replicates them. Yet, we argue that existing work leaves out an important part of the story: the effect that third parties have on the distributional consequences of early settlements. Put differently, we believe the early settlements that occur in the presence of third parties will lead to more evenly distributed market access granted by the defendant to the remainder of the membership. Indeed, we are interested less in the pay-offs of third parties themselves than in the effect of their presence on everyone else's pay-offs.

To be clear, we do not claim that third parties enter the room with the goal of preventing bilateral opportunism. They may join for a number of reasons, all of them based on self-interest. As mentioned, countries have been shown to join disputes as a means of learning, and building legal capacity. ${ }^{60}$ This is often the reason given for China's fervent participation in all disputes it could join after its entry into the organization. States may also want to join a dispute in order to urge the panel to be circumspect in its handling of important, sensitive issues if a ruling may have important implications for future WTO jurisprudence. Finally, countries join as third parties to ensure that their interests are represented in legal decisions that affect them. ${ }^{61}$ In this way, the enforcement function of third parties is a by-product of their presence in the room,

53 Alschner 2012.

54 Bagwell and Staiger 2004.

55 Bagwell and Staiger 2004.

56 Bechtel and Sattler 2011; Bown 2005; Johns and Pelc 2013.

57 Busch, Reinhardt, and Shaffer 2009.

58 Busch and Reinhardt 2006; Davey and Porges 1998.

59 Busch and Reinhardt 2006. Interestingly, a recent finding shows that non-litigants may be aware of this effect, and may choose not to join precisely to avoid acting as involuntary spoilers (Johns and Pelc 2013).

${ }^{60}$ Busch, Reinhardt, and Shaffer 2009.

61 Bown 2004. 
rather than the reason for it. If third parties play an unwitting enforcement function by warding off discriminatory settlements in a way that the existence of rules by itself cannot, then the membership as a whole will benefit from their presence, despite the effect they may have on the odds of any deal being reached in the first place. In sum, the branding of third parties as net spoilers may have been premature.

Yet, the hypothesized effect of third parties should only be seen under certain circumstances. Given our theory, any enforcement effect will be limited to instances in which, in the absence of third parties, discriminatory settlements would be difficult to police. As per Hypothesis 1 above, this scenario is most likely during consultations. The private nature of consultations implies a higher likelihood of inequitable settlements. Conversely, once a ruling is reached and recommendations for compliance are made public, all members observe the outcome of the ruling, and expectations converge regarding what would constitute compliance.

For these reasons, in cases in which the rulings have reduced informational asymmetries, third parties should have less of an enforcement role to play. Third parties shine a light on otherwise private consultations, reducing the potential for discrimination by illuminating the terms of any settlement. Taken together, this logic leads to our second hypothesis. If third parties play an unwitting enforcement function, then:

HYPOTHESIS 2: Third parties' presence should increase the gains of the rest of the WTO membership, but only for disputes that conclude before a ruling.

\section{RESEARCH DESIGN}

To test our hypotheses, we construct a new database containing dispute histories and trade flows for each WTO dispute from DS1 to DS420 that names specific goods. ${ }^{62}$ The data amount to what we believe is the fullest available record of trade relations between WTO members in disputed products. Our unit of observation is dispute-trade partner-year, where 'trade partner' refers to all complainants, third parties and non-participants that trade with the defendant. For reasons described below, we only include disputes for which there exists a complete record of trade data. This yields a sample of 242 disputes (involving a total of 260 complainants, 650 third parties and 6,800 non-participants).

\section{Dependent Variable}

To test our hypotheses, we analyze trade flows after disputes end between defendants and their trade partners. ${ }^{63}$ Specifically, we observe the annual volume of imports into defendants from each WTO member over the five-year period after a dispute ends. If the dispute settlement procedure is working effectively, it should help dismantle discriminatory barriers, and we should observe greater inflows of trade after disputes across members.

Since we rely on levels, we are careful to control for the possibility that countries that conduct more trade ex ante have more to gain from disputes. Indeed, countries may select themselves into the role of complainant for precisely this reason. Modeling dispute initiation would be the

\footnotetext{
${ }^{62}$ Not every case involves trade; some are 'non-merchandise' disputes, which concern broader domestic rules and practices - e.g., DS402 on the use of 'zeroing' in US anti-dumping determinations.

63 An alternative strategy would be to assess how discriminatory the market concessions states grant at the end of a dispute are. However, reliable data on trade policy changes are scant, especially following settlements prior to a ruling. More importantly, there is always a gap between announced and applied policy changes. Our approach effectively accounts for this gap: we are interested in the de facto market access that states are able to secure from defendants.
} 
best way to analyze the non-random assignment of complainant status. Unfortunately, this is notoriously difficult, as it requires modeling 'the dogs that don't bark' ${ }^{64}$ However, we can ensure that our results are not driven solely by the material stake in a dispute. By comparing the gains of the complainant to the broader membership, we are able to distinguish the impact of privacy from the strength of the bilateral trade relationship prior to a case being filed.

To construct our measure, we start with bilateral import data for each product named in merchandise disputes using data from the United Nations' Comtrade database, which we access through the World Bank's World Integrated Trade Solution. Imports are initially recorded at the classification level referenced in the complaint (either 2-, 4- or 6-digit Harmonized System codes). ${ }^{65}$ We then collapse the import data by dispute-partner-year, summing the productspecific data into one yearly indicator of imports of disputed products.

We cast our analysis at the dispute level (rather than the product level) for two reasons. First, we have no a priori theoretical reason to expect that products are affected differently within the same dispute. Secondly, disputes vary widely in the number of products they name. Across the sample, the mean number of products is five, while the median is only two. A plurality of disputes name a single product (141 cases), while others name as many as thirteen (DS220) or even thirty-one (DS253). In a product-level analysis, cases that cite more goods would be weighted disproportionately in the sample.

As a result, we rely on a dispute-level analysis in which the dependent variable, Disputed Imports $_{i, j, t}$, is the annual level of imports into defendant $i$ from trade partner $j$ in year $t$. We $\log$ this variable to correct for the highly skewed nature of the distribution. (Bown and Reynolds emphasize the wide variation in trade values at stake across disputes. ${ }^{66}$ )

We only include product lines for which a complete record of trade data is available for five years after the dispute ends. It is important to omit products with missing values, because their disappearance (and reappearance) in the sample will create artificial drops (or jumps) in trade flows over time. ${ }^{67}$ The end of the dispute is defined as the year when the last official action was notified to the WTO. Ongoing cases are omitted because there is no settlement reported or ruling issued. Thus, the five-year period we analyze starts the year after a mutually agreed solution or ruling is notified. Using this cut-off point, as opposed to looking further into the future, creates a more conservative test. Including additional observations would increase the likelihood that we find an upward trend in post-dispute trade flows. However, it does effectively limit our sample of disputes ranging from DS1 to DS396.

Substantively, using import levels allows for direct comparisons between the trade conducted by different categories of WTO members. This is the most fitting approach when trying to identify discrimination - that is, situations in which some benefit from settlements disproportionately more than others. Specifically, it allows us to test whether complainants, on average, get greater levels of market access to respondents than do non-participants.

${ }^{64}$ To our knowledge, no study of WTO dispute settlement has successfully done this, since it requires data on all violations that could be pursued legally, and an account of the lobbying dynamics that influence which cases are pursued. Davis (2011) may come closest to achieving this, looking specifically at the United States.

${ }_{65}$ This is consistent with the data provided by Horn and Mavroidis (2008), on which we expand here.

${ }^{66}$ Bown and Reynolds 2014.

67 We also omit defendant-trade partner dyads with zero trade between them. We do not have a prediction about whether dispute settlement (of any outcome) generates new trade relationships between states that previously conducted zero trade. Nor do we expect either sampling restriction to bias our inferences. The vast majority of disputes involve developed markets with generally complete and reliable trade data at the product level. Missing data among these are likely to be random. More importantly, while we lose some information on trade in specific products, every country that has been a defendant in a dispute during the relevant period is represented in our sample. Therefore, we are not systematically excluding countries involved in disputes. 
An additional benefit of using levels, and the common baseline it implies, is that it allows for the most straightforward interpretation of our results. An alternative approach would be to look at changes in trade, which would show us the rate at which an individual country's trade is 'recovering' after a dispute. We might expect faster rates of recovery in the wake of disputes related to those countries reaping benefits from discriminatory settlements that advantage them at the expense of others. Accordingly, we re-ran our analyses below using the annual difference between pre- and post-dispute imports. The estimates are consistent with our baseline findings.

\section{Independent Variables}

The analysis relies on two main independent variables. In Models 1, 2 and 3, we explore the prevalence of discriminatory settlements. According to Hypothesis 1, defendants should import more from complainants than from non-participants. We construct a variable Complainant $_{j, d}$ that is coded 1 if a member $j$ is a complainant in dispute $d$, and 0 otherwise. The sample for Models 1-3 includes all trade partners in each dispute, meaning that the reference category for the coefficient on Complainant $_{j, d}$ is all non-complainant WTO members. If discrimination occurs, we expect a positive, significant coefficient, indicating that complainants conduct significantly greater volumes of trade with defendants relative to members outside the room.

In the second set of tests (Models 4-9), we explore the role that third parties play in preventing discrimination. Our theory predicts that third parties reduce the degree to which early settlements result in asymmetric distributions of trade benefits. We test this proposition in two ways. First, we explore the extent to which third parties increase the amount of trade that nonparticipants conduct with respondents in general (Models 4-7). We expect that trade with nonparticipants increases, all else equal, if third parties are playing an 'enforcement role' - that is, third parties ensure that early settlements do not discriminate against members outside the room. We use a simple count of third parties in Model 4, as well as alternative forms of the variable. These include a dichotomous indicator of any third-party participation (Third-Party Dummy D $_{\text {) }}$ in Model 5, which tells us whether a single third party in the room is sufficient to observe an enforcement effect. We also use a logged count (Third Parties Logged L $_{\text {) }}$ in Model 6 to account for the potential of a non-linear relationship between third-party participation and post-dispute trade. Finally, we weight the count of third parties by the average amount of trade between third parties and the defendant in a disputed product (Third Party Weighted W $_{\text {) }}$ in Model 7. This allows us to evaluate the proposition that third parties may only play an enforcement role when they have high levels of material interest in the dispute.

Note that in Models 4-7, we restrict the sample to non-participants only. We do this because we first want to establish that third-party participation increases the amount of market access that non-participants gain to respondent markets. A positive coefficient on any of our thirdparty variables is evidence that non-participants' pay-offs increase as the number of eyes in the room increases.

Our second approach then broadens the sample to look at the difference between complainants and non-participants. In Model 8, we introduce a dichotomous indicator of Complainant $_{j, d}$ status, which we expect to be positive since complainants ought to be gaining more in early settlements. We then interact Complainant $_{j, d}$ with a simple count of the number of Third Parties $_{d}$ in each dispute $d$. This model uses the entire sample of WTO members since it makes a more direct comparison between the pay-offs enjoyed by complainants relative to non-participants (Model 9). This interaction tells us whether complainants' pay-offs increase in the presence of third parties in the dispute. Our theory suggests that it should not. While we 
expect third parties to have a positive effect on non-participants' trade through their unwitting enforcement function, they should not have the equivalent effect on complainants' trade (see Model 9).

\section{Control Variables}

Each model includes variables to control for confounding factors. First, we include the market size of both the defendant and partner country, measured as the logged value of GDP in constant year 2000 US dollars, taken from the World Bank's World Development Indicators. These variables - Defendant $G D P_{i, t}$ and Trade Partner $G D P_{j, t}-$ control for the fact that countries with larger markets are likely to conduct more trade in any given good. Moreover, larger markets may be better able to secure deeper concessions during disputes because they can more credibly threaten retaliation. Thus controlling for GDP has the added benefit of capturing relative market power, not just the size of the members. As stated at the beginning of the article, power has been shown to be an important determinant of the benefits of international institutional membership. Including market size helps control for this possibility.

We also include a measure of whether the countries in each defendant-trade partner pair are democracies. Using a dichotomous indicator of democracy, we generate Democratic Pair ${ }_{i, j, t}$, which is coded 1 if both the defendant and partner are democracies. We might expect that democracies are less likely to enter into discriminatory settlements if they are compelled by domestic audiences to behave in a more transparent manner. Conversely, democratic pairs of countries may be more likely to strike discriminatory deals, given their vulnerability to domestic interests. We rely on Cheibub, Gandhi and Vreeland's coding of democracy. ${ }^{68}$

In addition, it is necessary to control for features of the bilateral trade relationship between defendants and their partners. We include the level of imports (in named products) between each defendant-partner pair in the year prior to the dispute (Disputed Imports $s_{i, j, t}$ ). Doing so controls for the starting trade position of each member. Additionally, we construct a measure of the logged total imports (for all products) from each partner, Total Imports $s_{i, j, t}$. This measure controls for whether the overall strength of trade ties is driving the asymmetry in post-dispute trade.

Note that we include dispute fixed effects to account for unobserved heterogeneity across disputes. Following the example set by Busch and Reinhardt, we combine dispute numbers where multiple complaints challenge the same issue. ${ }^{69}$ Therefore, when eight countries challenge US steel safeguards in 2002 we count this a single dispute, since all eight disputes were filed at the same time and yielded a single panel ruling. Fixed effects control for disputespecific features that might affect the distribution of trade between members, including the direction of the ruling and the overall 'strength' of the case, which we can think of as the legal merit of the claims made. This would also help control for features like the duration of the dispute, since the length of time that a disputed policy is in place may affect trade flows by influencing, for example, the time it takes for the market to adjust. ${ }^{70}$

Finally, we recognize that dispute outcomes are non-random. This is particularly true when exploring the role played by third parties, which are known to affect the outcome of disputes. ${ }^{71}$ We test for selection in both sections of our analysis and only find potential for bias in our tests of third parties. We describe our approach to correcting for selection below.

68 Cheibub, Gandhi, and Vreeland 2009.

69 Busch and Reinhardt 2006.

${ }^{70}$ We do not use country- or dyad-specific fixed effects because our main variable of interest - whether the partner country is a complainant - is time invariant within country and dyad IDs.

71 Busch and Reinhardt 2006. 
ANALYSIS AND RESULTS

We now (1) test the existence of discriminatory settlements and (2) explore whether third parties deter this discrimination. To preview our main findings, Models 1, 2 and 3 show that the distributional gains from early settlement are spread unevenly across the WTO membership (Hypothesis 1). Complainants fare much better under early settlement than do third parties and non-participants. Conversely, complainants do no better once a public ruling has been handed down. In Models 4-8, we show that third parties decrease the likelihood of early settlement a result consistent with the existing literature - and, crucially, that third parties reduce asymmetries in the pay-offs between complainants and the membership at large (Hypothesis 2).

\section{Models 1-3: How Prevalent Is Discrimination Under Privacy vs. Publicity?}

Disparities between the pay-offs received by complainants and the broader WTO membership are evidence that the concessions secured in private consultations are spread unevenly across the membership. We run a series of fixed-effects models to account for the possibility that unobserved features of each dispute shape trade. ${ }^{72}$ We cluster the standard errors by dispute number. Models 1-3 utilize the following baseline specification:

$$
\begin{aligned}
\text { Disputed Imports }_{i, j, t}= & \beta_{0}+\beta_{1} \text { Complainant }_{j, d}+\beta_{2} \text { Defendant GDP }_{i, t}+\beta_{3} \text { Partner GDP }_{j, t} \\
& +\beta_{4} \text { Democratic Pair }_{i, j, t}+\beta_{5} \text { Disputed Imports }_{i, j, t-1} \\
& +\beta_{6} \text { Total Imports }_{i, j, t}+\alpha_{d}+\mu_{i, j, t}
\end{aligned}
$$

where $\alpha_{d}$ is a dispute-specific fixed effect and $\mu_{i, j, t}$ represents the error term.

We perform the same regression exercise on three samples: (1) all WTO disputes (Model 1), (2) disputes that concluded with an early settlement (Model 2) and (3) disputes that reached a panel ruling (Model 3). To reiterate, we are looking for differences between defendants' trade with complainants and their trade with non-participants within each outcome. In other words, we are looking for relative gains for complainants, rather than absolute increases in post-dispute trade.

All WTO disputes, including early settlements and rulings. Model 1 estimates the average trade that complainants get from participating in disputes of any outcome (Column 1 in Table 1). The model provides a good overall fit to the data. ${ }^{73}$ The controls for import trends and total penetration are strong predictors of post-dispute levels. As expected, both are positively associated with imports.

The coefficient on Complainant $_{j, d}$ is positive, but it falls just short of significance at the 10 per cent level. ${ }^{74}$ Figure 2 displays the substantive effects. Post-dispute import flows are predicted to be 14.28 [14.06, 14.49] in logged dollars for complainants, as opposed to $14.09[14.08,14.10]$ for non-participants. ${ }^{75}$ This amounts to a difference of $\$ 275,000$, or an increase of 21 per cent in annual imports (a change from $\$ 1.31$ to $\$ 1.59$ million).

\footnotetext{
72 The results are largely consistent when using random effects. However, a Hausman test confirms that fixed effects are more appropriate in our setting $\left(\chi^{2}=50.85, \mathrm{p}<0.000\right)$.

73 The R-squared is 0.50 and the F statistic is $711.99(\mathrm{p}<0.000)$.

74 Recall that the models reported here use an indicator of import levels, but that the estimates are consistent when using import changes.

${ }^{75}$ All substantive effects are reported in logged dollars and include the 95 per cent confidence interval in brackets.
} 
та в Le 1 How Does Privacy vs. Publicity Affect the Distribution of Benefits?

\begin{tabular}{|c|c|c|c|}
\hline & Model 1 & Model 2 & Model 3 \\
\hline & All Disputes & Early Settlements (Privacy) & Rulings (Publicity) \\
\hline \multirow{2}{*}{ Complainant $_{j, d}$} & 0.186 & $0.430^{*}$ & 0.062 \\
\hline & $(0.113)$ & $(0.180)$ & $(0.136)$ \\
\hline \multirow{2}{*}{ Defendant $G D P_{i, t}$} & $1.471 * *$ & $2.228 * *$ & $1.457 * *$ \\
\hline & $(0.030)$ & $(0.640)$ & $(0.035)$ \\
\hline \multirow[t]{2}{*}{ Partner $G D P_{j, t}$} & $0.082 * *$ & 0.060 & $0.089 * *$ \\
\hline & $(0.026)$ & $(0.039)$ & $(0.032)$ \\
\hline \multirow[t]{2}{*}{ Democratic Pair $_{i, j, t}$} & -0.070 & -0.093 & -0.065 \\
\hline & $(0.077)$ & $(0.109)$ & $(0.101)$ \\
\hline \multirow[t]{2}{*}{ Disputed Imports $_{i, j, t-1}$} & $0.823^{* *} *$ & $0.858 * *$ & $0.807 * *$ \\
\hline & $(0.019)$ & $(0.028)$ & $(0.023)$ \\
\hline \multirow[t]{2}{*}{ Total Imports Ii,j, } & $0.123 * *$ & $0.097 *$ & $0.138 * *$ \\
\hline & $(0.027)$ & $(0.040)$ & $(0.034)$ \\
\hline \multirow[t]{2}{*}{ Constant } & $-39.239 * *$ & $-59.797 * *$ & $-39.297 * *$ \\
\hline & $(0.978)$ & $(18.242)$ & (1.177) \\
\hline $\mathrm{N}$ & 18,093 & 6,027 & 12,066 \\
\hline R-squared & 0.76 & 0.77 & 0.76 \\
\hline
\end{tabular}

Note: clustered standard errors in parentheses. The samples in these models vary. Model 1 looks at all disputes, Model 2 looks only at disputes that settle early (private) and Model 3 looks only at disputes that end in rulings (public). The dependent variable is imports after the dispute into the defendant market. The level of analysis is the country-product-year level. The coefficient on Complainant indicates whether complainants enjoy significantly more (or less) market access than nonparticipants. $* \mathrm{p}<0.05, * * \mathrm{p}<0.001$
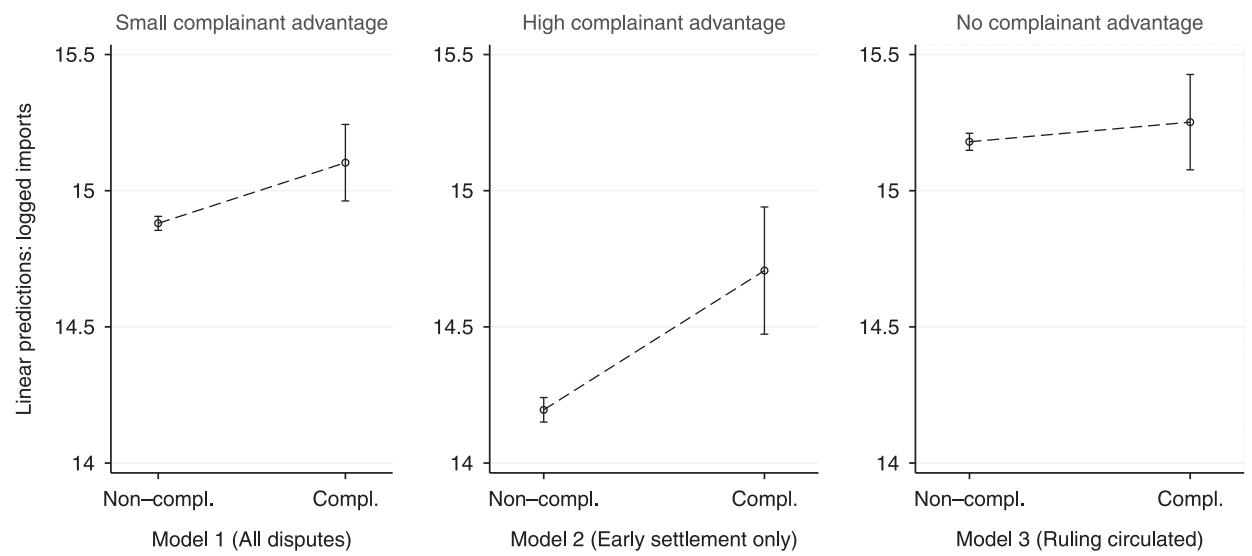

Fig. 2. Substantive advantage of complainant over others, by dispute stage reached

Disputes that ended in early settlement. Model 1 relies on a sample of all dispute outcomes. However, our prediction is that discrimination is most likely to occur during early settlements (Hypothesis 1). ${ }^{76}$ Model 2 confirms this expectation (Column 2 in Table 1). Complainants enjoy

\footnotetext{
${ }^{76}$ To be clear, early settlements are defined as disputes in which both parties officially notify the WTO of a mutually agreed solution. The latter condition is important, as there is sometimes disagreement over whether a
} 
a clear benefit in cases that settle early (30.4 per cent of our sample) when their trade flows are compared to the rest of the membership. This advantage is statistically significant at the 0.05 level, and it is substantively large: complainants receive a 68 per cent larger volume of postdispute imports than the other members, on average. Complainants receive 13.53 [13.19, 13.87] compared to the $13.09[13.08,13.11]$ received by non-participants (Figure 2), or an annual difference of $\$ 750,000$ to $\$ 484,000 .{ }^{77}$ While the difference of $\$ 266,000$ is roughly the same in absolute terms as the effect found in Model 1, it represents a far greater relative increase given the smaller amount of trade resulting from early settlements. Model 2 confirms that complainants do much better than other members in early settlements.

These estimations also allow us to verify whether power magnifies the odds of collusion: might it be that powerful complainants are better than others at exploiting privacy to obtain unfairly favorable settlements? If so, this might account for why the regime's great powers would be especially tolerant of the current institutional design. To find out, we first rerun Model 2 on a restricted sample that omits instances in which the United States or the EU are complainants, and find that the result holds. More interestingly, however, we look at whether the United States or the EU gains even more, relative to others, in private settlements. We find only a small substantive difference between the predicted trade for great power complainants (13.72 [12.24, 15.32]) and all other complainants (13.39 [12.22, 14.55]). Varying the complainant's market power from the 50th to the 75th percentile yields similarly little effect. In sum, power appears to have a negligible impact on the complainant's ability to extract discriminatory settlements under privacy.

Disputes that reached a ruling. We now test the corollary that there should be no perceptible difference between complainant and non-participant trade under public rulings. Model 3 confirms the effect of privacy on outcomes by showing what happens in its absence. Once litigation begins, and the stakes of the dispute are publicized for all to see, complainants no longer do better than other WTO members. We re-estimate the same model as above on disputes that do not settle early (which corresponds to 69.6 per cent of the cases in our sample) and find that complainants do not do better than third parties or non-participants (Column 3 in Table 1). The difference between imports from complainants and the rest of the membership is a negligible $\$ 75,000$, an increase of 4 per cent for complainants over non-participants.

We also re-estimated Model 3 using just a sample of disputes in which the complainant won, since complainants may only receive trade benefits when they win a dispute. Depending on how the direction of a ruling is measured, complainants are victorious in almost every case. Using data on the direction of the ruling on each individual legal claim in the dispute, we restricted the sample to cases in which the complainants won at least one claim, and the results were consistent with Model $3 .^{78}$

These estimates suggest that, on average, early settlements favor the complainant disproportionately more than cases that result in panel rulings. Overall, complainants do significantly better than other trade partners, be they third parties or non-participants, but only if the dispute is

solution is truly mutually agreeable, as in EC-Bananas III, when the European Communities notified an understanding with the United States and Ecuador as a mutually satisfactory solution within the meaning of Article 3.6 of the DSU, but both Ecuador and the United States disagreed, and asked that the dispute not be taken off the Dispute Settlement Body (DSB) agenda.

77 Note that the confidence interval is wider around the prediction for complainants in part because there are far fewer complainants in the sample than non-participants.

78 They are also robust to an alternative restriction: whether the complainant won at least half of the legal claims made. 
concluded in private. Under publicity, everyone benefits just the same. As a result, it appears that the feature of the DSU most commonly believed to facilitate settlement - private consultation - leads to trade outcomes that are fundamentally at odds with another core feature of the regime: non-discrimination.

Before moving on, we re-ran each of these three models using a Heckman correction for nonrandom selection (described in additional detail below). The possibility of selection bias is a greater concern in our tests of the role of third parties. However, it remains important to ensure that these first baseline estimates are not contaminated by selection. We retested Models 1-3 using a Heckman approach and found no evidence of bias. The coefficients remain consistent with those reported in Table 1, and the Wald test statistic is strictly insignificant, suggesting that selection and outcome equations can be treated as independent.

Alternative explanations. Is there an alternative explanation for our results? Since states are likely to sue based on their material stake in the disputed issue, one might argue that we should expect complainants to 'win' more from settlements. If complainants simply have more to gain, or if the nature of the disputed policy is inherently bilateral, then observing larger gains for complainants need not imply discrimination.

Yet the mere existence of inherently bilateral disputes - that is, cases such as anti-dumping disputes that affect the complainant more than the remainder of the membership - is in itself insufficient to undermine our results. For bilateral disputes to affect our results, it is necessary that they be distributed non-randomly across different dispute outcomes. This is precisely the strength of our research design, which isolates disparities in trade across members under different dispute outcomes. To conclude that the greater gains to complainants associated with early settlement are due to the inherent bilateralism of certain disputes - for example, anti-dumping disputes - they would need to have a higher likelihood of settling early. In other words, it would have to be true that cases involving bilateral issues are significantly more likely to be settled during private consultations if our results were driven merely by complainants having more to gain.

We examine this premise and find no support for it. Consider the distribution of the ten most commonly cited agreements in disputes across outcomes, as shown in Table 2. The table does not support the claim that disputes involving inherently bilateral measures are more likely to settle early. If anything, anti-dumping cases, which form the most likely category of inherently bilateral disputes, appear more likely to go to court. As a result, there is no reason to believe that the evidence from Models 1-3 is driven by the fact that complainants simply 'have more to gain' from dispute participation. We evaluate this relationship more directly in robustness tests below and find that there is no systematic relationship between the disputed issue and either the likelihood of early settlement or the distribution of pay-offs.

Another critique may be that non-participants still win under early settlement, even if they win less than complainants. If true, non-participants may have a preference for early settlement because they still receive some non-zero boost in post-dispute trade. We examine this possibility and find it to be false. The average value of annual trade from non-participants into defendants' markets after an early settlement is $\$ 1.67$ million. After a case goes to panel, it is nearly double that, at $\$ 2.95$ million. Non-participants therefore stand to gain significantly more when cases go to court. This is further supported by the aggregate gains once disputes have ended. The average total trade from non-participants into defendants' markets over the five years following a ruling is $\$ 1.18$ billion. After early settlements, this average is only $\$ 690$ million. Again, non-participants get nearly twice as much following panel rulings as they do 
тAв LE 2 The Distribution of Major Legal Claims across Dispute Outcomes

\begin{tabular}{lcc}
\hline \hline & Early Settlement & Ruling \\
\hline Agriculture & 4 & 11 \\
Anti-dumping & 6 & 24 \\
Safeguards & 3 & 14 \\
Services & 2 & 4 \\
SPS & 6 & 5 \\
Subsidies & 6 & 6 \\
TBT & 6 & 6 \\
Textiles & 5 & 4 \\
TRIMs & 0 & 14 \\
TRIPs & 3 & 2 \\
\hline \hline
\end{tabular}

following early settlements. These numbers suggest that, under early settlements, nonparticipants are demonstrably losing from bilateral opportunism.

Finally, if complainants are winning more because they have more to gain, this would not explain differences in the results between early settlements and rulings. Instead, it would imply that complainants benefit significantly more from disputes of all types. However, we fail to find a similar disparity when looking at cases that went to rulings. For these reasons, we conclude that our evidence points to the existence of discriminatory settlements that result directly from the private nature of early settlements.

\section{Models 4-9: Do Third Parties Prevent Discrimination?}

Our first set of tests found that privacy is at odds with the equitable treatment of trade partners as envisaged under the WTO's rules. Our theory also predicts that third-party participation helps reduce discrimination (Hypothesis 2).

As previewed, exploring the role of third parties requires a different estimation approach. Dispute outcomes are assigned non-randomly. The existing literature shows that third-party participation affects the likelihood that disputes will proceed to the ruling stage. Failing to correct for this selection process will bias our estimates of third parties' effects on trade. Therefore, we estimate a series of Heckman selection models that allow us to isolate the effects that third parties have on both (1) the likelihood of early settlement and (2) post-dispute import levels. As above, we cluster the standard errors by our combined dispute identifier. The selection equation is specified as:

$$
\begin{aligned}
\text { Early Set. }= & \beta_{0}+\beta_{1} \text { Third Parties }_{d}+\beta_{2} \text { Defendant GDP }_{t}+\beta_{3} \text { Partner GDP }_{t} \\
& +\beta_{4} \text { Democratic Pair }_{i, j, t}+\beta_{5} \text { Disputed Imports }_{i, j, t-1}+\beta_{6} \text { Total Imports }_{i, j, t} \\
& +\beta_{7} \text { Claims Number }_{d}+\mu_{i, j, t}
\end{aligned}
$$

Note that we add a variable in the selection stage for the number of individual legal claims made by the complainants, which is usually seen as evidence of a weak case, and a legal 'kitchen sink strategy' ${ }^{79}$ This measure, Claims Number ${ }_{d}$, is a count of the WTO articles cited in the dispute. This addition is required to ensure that our system of equations is identified

${ }^{79}$ Busch and Reinhardt (2006) define this as 'tacking on additional claims precisely when they [the complainant] are less confident of the merits of each separate claim'. 
appropriately. ${ }^{80}$ This variable performs well across the models. It bears no relation to our second-stage dependent variable, yet shows the predicted relationship with the likelihood of early settlement.

We explore third parties' effects in two different ways. To start, we restrict the sample to nonparticipants only. Here, the coefficient on Third Parties $d$ is the amount of trade that nonparticipants enjoy for each increase in the number of third parties. Model 4 presents the results when using a count of third parties as the explanatory variable (Table 3 ).

Note that the $\chi^{2}$ statistic is $58.12\left(\chi^{2}<0.000\right)$, suggesting that the selection and outcome equations are not independent, and that the Heckman correction is required. Looking at the selection equation, we see that third parties significantly decrease the likelihood of early settlement, which is consistent with what we know about how third parties extend the length of disputes. Importantly, however, prior work on third-party participation led to the conclusion that third parties may prevent mutually beneficial settlements. The findings above allow us to qualify this view, suggesting that third-party participation is not strictly inefficient. Third parties unwittingly prevent the types of settlements that disadvantage the WTO membership at large.

The outcome equation illustrates the effects that third parties have on the pay-offs received by non-participants. The results show that third parties have a significant, positive impact on post-dispute import levels for the membership $(\mathrm{p}<0.018)$. The exponentiated coefficient corresponds to the percentage by which imports grow for each additional third party in the room. The average import level for non-participants in the wake of disputes with no third parties is $\$ 1.9$ million. The inclusion of one third party in the room, according to the estimates, increases average post-dispute imports to over $\$ 3.5$ million, or a nearly 80 per cent increase in bilateral trade between non-participants and the defendant.

We infer that third-party participation has a non-negligible positive effect on nonparticipants' trade after early settlement. More generally, this evidence shows that defendants and complainants strike significantly fewer discriminatory deals when third parties are in the room. Any market access granted to complainants is extended to the entire membership when third parties are allowed to observe the terms of deals being reached. Note that we do not test an additional source of selection here - namely, that higher stakes in a dispute lead to a greater number of third-party participants. However, we do control for existing trade levels between defendants and their partners in both the selection and outcome equations, thereby taking note of the amount of trade at stake in the dispute.

Model 4 relies on a simple count of the number of third parties. However, there is good reason to try alternative codings. These models yield stronger results. To being with, Model 5 tests whether any third-party participation is sufficient to prevent discrimination (Model 5 in Table 3). Since this coding reduces all non-zero third-party values to 1 , it produces a large substantive effect; imports grow by a factor of 3.43 when comparing cases with no third parties to those with at least one.

The results are also consistent when using the logged count of third parties (Model 6). ${ }^{81}$ In our sample, there are only five disputes with more than fifteen third parties. The mean number is 3.2 and the median is only 1. Only a few disputes, such as DS265 and DS266 (over EU sugar subsidies), include twenty or more third parties. The skewed nature of the count variable leaves open the possibility that outliers are driving the results. We test for this, and the estimates are consistent when using the logged count (Model 6 in Table 3).

\footnotetext{
${ }^{80}$ We also ran models using the percentage of the complainants' previous disputes that went to panel. It may be the case that certain complainants are systematically more likely to pursue their claims and are therefore less likely to settle early. In both cases, the substantive interpretation of the results remains constant.

81 Calculated as: Third Parties Logged L $=\log \left(\right.$ Third Parties $\left._{d}+1\right)$.
} 
T A B L 3 Do Third Parties Increase Pay-offs to Non-participants?

\begin{tabular}{|c|c|c|c|c|c|c|c|c|}
\hline & \multicolumn{2}{|c|}{ Model 4} & \multicolumn{2}{|c|}{ Model 5} & \multicolumn{2}{|c|}{ Model 6} & \multicolumn{2}{|c|}{ Model 7} \\
\hline & $\begin{array}{l}\text { Selection } \\
\text { Early Set. }\end{array}$ & $\begin{array}{l}\text { Outcome } \\
\text { Imports }\end{array}$ & $\begin{array}{l}\text { Selection } \\
\text { Early Set. }\end{array}$ & $\begin{array}{l}\text { Outcome } \\
\text { Imports }\end{array}$ & $\begin{array}{l}\text { Selection } \\
\text { Early Set. }\end{array}$ & $\begin{array}{l}\text { Outcome } \\
\text { Imports }\end{array}$ & $\begin{array}{l}\text { Selection } \\
\text { Early Set. }\end{array}$ & $\begin{array}{c}\text { Outcome } \\
\text { Imports }\end{array}$ \\
\hline Third Parties $_{d}$ & $\begin{array}{c}-0.236^{* *} \\
(0.065)\end{array}$ & $\begin{array}{c}0.804 * \\
(0.340)\end{array}$ & & & & & & \\
\hline Third-Party Dummy ${ }_{d}$ & & & $\begin{array}{l}-1.132 * * \\
(0.262)\end{array}$ & $\begin{array}{r}3.434 * \\
(1.487)\end{array}$ & & & & \\
\hline Third Parties Logged $d$ & & & & & $\begin{array}{l}-0.688 * * \\
(0.162)\end{array}$ & $\begin{array}{l}2.320 * * \\
(0.894)\end{array}$ & & \\
\hline Third Parties Weighted ${ }_{d}$ & & & & & & & $\begin{array}{c}-0.058 * * \\
(0.014)\end{array}$ & $\begin{array}{c}0.065^{*} \\
(0.025)\end{array}$ \\
\hline Defendant $G D P_{i, t}$ & $\begin{array}{r}-0.097 \\
(0.076)\end{array}$ & $\begin{array}{r}-0.021 \\
(0.310)\end{array}$ & $\begin{array}{r}-0.095 \\
(0.077)\end{array}$ & $\begin{array}{r}-0.058 \\
(0.289)\end{array}$ & $\begin{array}{r}-0.102 \\
(0.077)\end{array}$ & $\begin{array}{r}-0.013 \\
(0.305)\end{array}$ & $\begin{array}{c}-0.184 * \\
(0.088)\end{array}$ & $\begin{array}{c}0.194 \\
(0.129)\end{array}$ \\
\hline Partner $G D P_{j, t}$ & $\begin{array}{c}0.003 \\
(0.048)\end{array}$ & $\begin{array}{c}-0.288 \\
(0.218)\end{array}$ & $\begin{array}{c}0.046 \\
(0.051)\end{array}$ & $\begin{array}{c}-0.434 \\
(0.227)\end{array}$ & $\begin{array}{c}0.013 \\
(0.049)\end{array}$ & $\begin{array}{c}-0.325 \\
(0.225)\end{array}$ & $\begin{array}{c}-0.013 \\
(0.059)\end{array}$ & $\begin{array}{c}-0.004 \\
(0.089)\end{array}$ \\
\hline Disputed Imports $_{i, j, t-1}$ & $\begin{array}{r}-0.007 \\
(0.025)\end{array}$ & $\begin{array}{l}0.727 * * \\
(0.122)\end{array}$ & $\begin{array}{c}-0.002 \\
(0.024)\end{array}$ & $\begin{array}{l}0.703^{* *} \\
(0.120)\end{array}$ & $\begin{array}{c}-0.006 \\
(0.024)\end{array}$ & $\begin{array}{l}0.721 * * \\
(0.121)\end{array}$ & $\begin{array}{c}-0.027 \\
(0.026)\end{array}$ & $\begin{array}{c}0.900 * * \\
(0.037)\end{array}$ \\
\hline Disputed Pair ${ }_{i, j, t}$ & $\begin{array}{c}0.062 \\
(0.052)\end{array}$ & $\begin{array}{r}-0.144 \\
(0.271)\end{array}$ & $\begin{array}{c}0.060 \\
(0.050)\end{array}$ & $\begin{array}{l}-0.117 \\
(0.255)\end{array}$ & $\begin{array}{c}0.062 \\
(0.051)\end{array}$ & $\begin{array}{l}-0.143 \\
(0.261)\end{array}$ & $\begin{array}{c}0.092 * \\
(0.044)\end{array}$ & $\begin{array}{c}-0.222 * \\
(0.097)\end{array}$ \\
\hline Claims Number ${ }_{d}$ & $\begin{array}{r}-0.039 * \\
(0.019)\end{array}$ & & $\begin{array}{r}-0.040 \\
(0.021)\end{array}$ & & $\begin{array}{r}-0.038^{*} \\
(0.019)\end{array}$ & & $\begin{array}{r}-0.057^{*} \\
(0.029)\end{array}$ & \\
\hline Total Imports $s_{i, j, t}$ & $\begin{array}{c}-0.006 \\
(0.038)\end{array}$ & $\begin{array}{c}0.545^{*} \\
(0.224)\end{array}$ & $\begin{array}{c}-0.045 \\
(0.045)\end{array}$ & $\begin{array}{c}0.698 * \\
(0.271)\end{array}$ & $\begin{array}{c}-0.014 \\
(0.039)\end{array}$ & $\begin{array}{c}0.580^{*} \\
(0.236)\end{array}$ & $\begin{array}{c}0.049 \\
(0.043)\end{array}$ & $\begin{array}{c}0.061 \\
(0.070)\end{array}$ \\
\hline Constant & $\begin{array}{c}2.545 \\
(2.338)\end{array}$ & $\begin{array}{c}9.676 \\
(8.689)\end{array}$ & $\begin{array}{c}2.299 \\
(2.417)\end{array}$ & $\begin{array}{l}11.059 \\
(8.144)\end{array}$ & $\begin{array}{c}2.679 \\
(2.406)\end{array}$ & $\begin{array}{c}9.428 \\
(8.771)\end{array}$ & $\begin{array}{c}4.640 * \\
(2.810)\end{array}$ & $\begin{array}{c}3.046 \\
(4.059)\end{array}$ \\
\hline $\begin{array}{l}\mathrm{N} \\
\chi^{2}\end{array}$ & 36,821 & (5,272 & 36,821 & ** 5,272 & 36,821 & 5, 5,272 & 33,157 & ** 4,423 \\
\hline
\end{tabular}

Note: Clustered standard errors in parentheses. These models run on a sample restricted to non-participants. The dependent variable is imports after the dispute into the defendant market. The level of analysis is the country-product-year level. The coefficient on Third Parties $d$ indicates whether nonparticipants' trade increases in third parties. $* \mathrm{p}<0.05, * * \mathrm{p}<0.001$ 
We also considered a trade-weighted count of third parties. One might think that the enforcement effect of third-party participation may be conditioned by their material stake in the dispute. In addition, the trade-weighted variable provides another way to get at the possible role played by market power. Our theory of third-party enforcement relies on eyes in the room, and does not hinge on third parties' material stake in the dispute. Nevertheless, we test for this possibility in Model 7 (Table 3). The results are consistent with all other specifications. The effect of third parties is not conditioned by the strength of their interest in the dispute, measured as bilateral trade with the defendant in the products at issue in the dispute. This finding, together with the fact that a simple dichotomous indicator of any third-party presence is equally significant, suggests that discriminatory deals are successfully deterred by extra eyes in the room, regardless of their number or the interests at stake.

Finally, we then approach the question from another angle. Models 8 and 9 look more specifically at the relative gains of complainants vs. non-participants (Table 4). For both models, the sample is made up of complainants and non-participants - that is, third parties are excluded. Model 8 includes our dichotomous indicator of complainant status in the outcome equation. It shows that complainants enjoy significantly greater access to respondent markets after early settlements. We then interact Complainant ${ }_{j, d}$ status with Third Parties $_{d}$ to see whether complainants conduct greater amounts of trade as the number of third parties increases (Model 9). The coefficient tells us whether trade between complainants and defendants is different from trade between non-participants and defendants. The results in Model 9 provide no evidence that complainants benefit disproportionately more than non-participants. The interaction term is negative, but not highly insignificant, suggesting that complainants are not doing better in the presence of third parties, and may be doing worse. As with all interaction effects, one needs to simulate quantities of interest to see what the substantive effect over the relevant data range is. Once we do so, the pattern is as our theory would suggest: in the presence of a single third party, complainants enjoy 1.6 times the amount of market access opening that non-participants do. As the number of third parties increases to ten, this gap falls to 1.18 times the amount.

In sum, Models 4-7 showed that the presence of third parties benefits non-participants. Models 8 and 9 show that there is no equivalent effect for complainants. If anything, complainants' advantage vis-à-vis others is eroded as the number of third parties increases. Taken together, Models 4-9 demonstrate two important effects of third-party participation. First, the findings echo previous work on the relationship between third parties and early settlement. The presence of these 'observers' significantly reduces the likelihood that states reach an out-of-court settlement. Secondly, we find strong evidence that, when early settlements do occur, the WTO membership benefits significantly from third-party participation. One caveat is warranted in this respect. We do not observe the partisanship of third parties during early settlement. The stance these parties take in the dispute (pro-complainant, pro-defendant or mixed) only becomes clear once cases go to litigation and third parties have the opportunity to submit opinions to the panel. Under mutually agreed solutions, by comparison, it is not immediately obvious which side of a dispute each party supports. Yet our story does not turn on which side third parties support. It requires only that their presence in the room prevents litigants from reaching deals that are customized to the exclusive interests of the complainant, at the expense of the greater membership.

Additional robustness checks. We explore the durability of our results by conducting a number of additional tests. ${ }^{82}$ First, it is possible that discriminatory settlements are more likely when great powers - defined here as the EU and the United States - are involved in the dispute.

\footnotetext{
${ }^{82}$ In the interest of space, we simply describe these tests. However, all estimation results are available from the authors.
} 


\begin{tabular}{|c|c|c|c|c|}
\hline & \multicolumn{2}{|c|}{ Model 8} & \multicolumn{2}{|c|}{ Model 9} \\
\hline & $\begin{array}{l}\text { Selection } \\
\text { Early Set. }\end{array}$ & $\begin{array}{l}\text { Outcome } \\
\text { Imports }\end{array}$ & $\begin{array}{l}\text { Selection } \\
\text { Early Set. }\end{array}$ & $\begin{array}{l}\text { Outcome } \\
\text { Imports }\end{array}$ \\
\hline Third Parties $_{d}$ & $\begin{array}{l}-1.135^{* *} \\
(0.250)\end{array}$ & $\begin{array}{l}0.735^{* *} \\
(0.247)\end{array}$ & $\begin{array}{l}-1.135^{* *} \\
(0.250)\end{array}$ & $\begin{array}{l}0.736^{* *} \\
(0.250)\end{array}$ \\
\hline Complainant $_{j, d}$ & & $\begin{array}{c}0.469 * \\
(0.222)\end{array}$ & & $\begin{array}{c}0.482 \\
(0.340)\end{array}$ \\
\hline 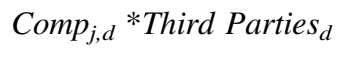 & & & & $\begin{array}{c}-0.006 \\
(0.107)\end{array}$ \\
\hline Defendant $G D P_{i, t}$ & $\begin{array}{r}-0.084 \\
(0.077)\end{array}$ & $\begin{array}{r}-0.074 \\
(0.271)\end{array}$ & $\begin{array}{r}-0.084 \\
(0.077)\end{array}$ & $\begin{array}{r}-0.074 \\
(0.271)\end{array}$ \\
\hline Partner $G D P_{j, t}$ & $\begin{array}{c}0.044 \\
(0.046)\end{array}$ & $\begin{array}{l}-0.290 \\
(0.175)\end{array}$ & $\begin{array}{c}0.044 \\
(0.046)\end{array}$ & $\begin{array}{r}-0.290 \\
(0.175)\end{array}$ \\
\hline Disputed Imports ${ }_{i, j, t-1}$ & $\begin{array}{r}-0.007 \\
(0.022)\end{array}$ & $\begin{array}{l}0.754 * * \\
(0.106)\end{array}$ & $\begin{array}{r}-0.007 \\
(0.022)\end{array}$ & $\begin{array}{l}0.754 * * \\
(0.106)\end{array}$ \\
\hline Democratic Pair $_{i, j, t}$ & $\begin{array}{c}0.074 \\
(0.049)\end{array}$ & $\begin{array}{c}-0.147 \\
(0.268)\end{array}$ & $\begin{array}{c}0.074 \\
(0.049)\end{array}$ & $\begin{array}{c}-0.147 \\
(0.268)\end{array}$ \\
\hline Claims Number $_{d}$ & $\begin{array}{c}-0.038 \\
(0.022)\end{array}$ & & $\begin{array}{c}-0.038^{*} \\
(0.022)\end{array}$ & \\
\hline Total Imports $_{i, j, t}$ & $\begin{array}{r}-0.042 \\
(0.043)\end{array}$ & $\begin{array}{l}0.542 * * \\
(0.190)\end{array}$ & $\begin{array}{r}-0.042 \\
(0.043)\end{array}$ & $\begin{array}{c}0.542^{*} \\
(0.190)\end{array}$ \\
\hline Constant & $\begin{array}{l}2.000 \\
(2.395)\end{array}$ & $\begin{array}{c}10.332 \\
(6.655)\end{array}$ & $\begin{array}{l}2.000 \\
(2.396)\end{array}$ & $\begin{array}{l}10.331 \\
(6.659)\end{array}$ \\
\hline $\begin{array}{l}\mathrm{N} \\
\gamma^{2}\end{array}$ & 43,699 & 5,702 & 43,699 & 5,702 \\
\hline
\end{tabular}

Note: Clustered standard errors in parentheses. These models run on the full sample of complainants and non-participants. The dependent variable is imports after the dispute into the defendant market. The level of analysis is the country-product-year level. The coefficient on Complainant ${ }_{j, d}$ indicates whether complainants enjoy significantly more (or less) market access than non-participants. ${ }^{*} \mathrm{p}<0.05,{ }^{* *} \mathrm{p}<0.001$

These states, which are involved in a huge number of WTO disputes, may use their legal expertise and/or their credible threat of retaliation in order to secure more favorable outcomes. We re-estimated our models with a restricted sample that omits great power complainants entirely, and the results remain consistent.

The United States and the EU may also be better able, for the same reasons, to prevent discriminatory settlements when they exercise their third-party rights. Indeed, these members are not just frequent complainants; they also participate regularly as third parties. The United States has been a third party on ninety-three occasions, the EU on 114 occasions. We re-estimate Model 5 by eliminating disputes in which either the United States or the EU is a third party. This change does not affect the baseline estimates. As a result of these two tests, we can say with some confidence that neither discrimination (nor its policing) is restricted to the major powers.

Another way to think about the importance of market power is to assess what 'great power' respondents are willing to concede. We re-ran Model 2 with a control for whether the respondent in the dispute was either the United States or the EU. ${ }^{83}$ We find that complainants

\footnotetext{
${ }^{83}$ Our dispute fixed effects already control for unobserved features of the respondent, since it does not vary within a dispute. However, we introduce a dichotomous indicator of US/EU respondent and run random effects so that we can get a specific estimate of their independent effects.
} 
enjoy significantly less market access when the respondent is a great power, suggesting that the United States and the EU may concede less under early settlements. The difference is substantively large - the US/EU receives just over $\$ 200,000$ in imports after early settlements, while all other respondents accept $\$ 4$ million, on average. However, we find that the significance of great power respondents diminishes when introducing an interaction between US/EU and complainant status. We also found no statistically significant difference once we controlled for non-random selection in early settlements, which are affected by the respondent's market power.

Finally, we run a series of tests to verify whether outcomes are driven by the disputed issue. As discussed above, Table 2 does not suggest any clear patterns. However, we can look more closely at these relationships by adding indicators of the issue at stake to our Heckman selection models. We introduce dichotomous indicators of the four most frequently cited agreements: anti-dumping, safeguards, agriculture and trade-related investment measures(s). The estimates do not reveal strong or consistent correlations between the disputed issue and either (1) the likelihood of early settlement or (2) the trade benefits enjoyed by non-participants. Most importantly, their inclusion does not affect the baseline estimates.

\section{DISCUSSION AND CONCLUSION}

This article explores a central question of global governance: How much transparency should there be in international institutions? On the one hand, privacy facilitates agreement. On the other hand, transparency allows for oversight. We explore this trade-off in the context of the global trade regime. We suggest that the very institutional design feature that is widely credited with promoting settlement - private consultations - may in fact be leading to outcomes that are fundamentally at odds with the WTO's core principle of non-discrimination.

Our analysis offers support for these expectations. The price to pay for the high rate of early settlement is that a significant proportion of these settlements is reached at the expense of the membership at large. As such, this article provides what is to our knowledge the first evidence of the existence of discriminatory settlements at the WTO. How might we explain this outcome? The design of rules is often chalked up to the preferences of powerful states. ${ }^{84}$ Superpowers may choose a level of legalization, for instance, that allows them sufficient influence at the margins. Yet power seems to play a small role in the present case: though WTO litigants are often powerful countries, we find no evidence that they are any more likely to collude or secure disproportionately favorable deals. Similarly, the market size of third parties seems to have little influence over their enforcement effect. How else to explain the suboptimal outcome we identify? The answer is largely historical. The WTO is an institution with diplomatic roots in which agreement has been the traditional priority (to this day, decisions are taken by consensus), and secrecy has been seen as a key means of securing it. As the character of the institution has turned increasingly legalistic, some rules have not evolved accordingly. This article suggests that the elevation of privacy during consultations may be one such example.

Although our analysis considers a particular institution that has long been faced with calls for greater transparency, other international institutions experience the same transparency trade-off. In these other settings, mechanisms have emerged to address the cost of privacy while maintaining some of the benefits of obfuscation, usually through some form of delegation. ${ }^{85}$

${ }^{84}$ Krasner 1991; Stone 2012.

85 The International Monetary Fund created its Independent Evaluation Office in 2001, the mission of which is to oversee arrangements reached between the Executive Board and national governments. The World Bank 
Yet it is domestic law that has grown most sophisticated in dealing with the trade-off that interests us. In the example of US antitrust law we mention above, the Tunney Act of 1974 requires a judge to confirm that any (otherwise private) settlement reached between the Department of Justice (DOJ) and a private firm is 'in the public interest'. ${ }^{86}$

The WTO has no comparable mechanism. On the evidence of the third parties effect we identify, one is tempted to think that this is where the solution must lie. Yet as we have stressed, the enforcement effect of third parties is a by-product of their defense of their own interests. Any design that would look exclusively to third parties to further deter discrimination would likely come up against a collective action problem, and enforcement would be underprovided. ${ }^{87}$ Our finding demonstrates that extra eyes deter discrimination. Yet while making third-party participation easier may be a partial answer, ${ }^{88}$ a fuller solution must lie elsewhere. The common means by which the World Bank, IMF and US antitrust law have addressed the opacity-transparency trade-off has been to let the negotiations themselves remain private and confidential, but to delegate authority to an independent actor over the social desirability of the settlement when one has been reached. The WTO's director general (DG) may be best suited to conduct such oversight. The DG is already involved in the specifics of disputes. ${ }^{89}$ Delegating approval of early settlements to the DG may also be a way of balancing the costs of privacy with possible concerns about the confidentiality of the business interests of private firms. DG approval would nonetheless hinge on having sufficient information about the content of a settlement to make this appraisal. The objective, in other words, should be to deter possible discriminatory deals by increasing information about them, rather than through enforcement power alone. Changes in this direction already appear increasingly likely. In recent discussions over dispute settlement reform, WTO members pushed for (and agreed on) revision of the key provisions of DSU Article 3.6, requiring a formal, written document relating the 'detailed terms' of each mutually agreed solution. ${ }^{90}$

Finally, this article also speaks to the strengths of a quantitative approach to the study of courts. Scholars studying judicial bias, for instance, cannot tell whether judges were biased in a given case - which allows judges to sometimes act based on personal interests or ideologies. Yet given a sufficiently large caseload, empirical legal scholars are able to detect the presence of bias in aggregate. ${ }^{91}$ In our case, given the lack of details about settlements, we would be unable to conclude from looking at a given case whether a discriminatory settlement has occurred or not. Indeed, that is why such discriminatory settlements are possible in the first place. Yet by leveraging the power of data covering all WTO disputes, and examining the subsequent trade

created an Inspection Panel in 1993, separate from the Bank's hierarchy, to hear claims that World Bank activities approved by national governments nonetheless harm communities or individuals (Kahler 2004).

${ }^{86}$ In the most salient Tunney Act finding of recent years, Judge Sorkin ruled that a settlement reached between the DOJ and Microsoft was 'not in the public interest' (Memorandum Opinion, United States of America $v$. Microsoft, Judge Stanley Sorkin, Civil Action No. 94-1564).

87 Thompson 2009.

88 Debates within the institution focus on how late in a dispute countries can join, for instance. The overall trend is toward ever-greater access to third parties.

${ }^{89}$ E.g., if the parties cannot agree on the selection of panelists, the DG appoints them (this now happens in more than half of all cases).

90 The proposed text reads as follows (revised or new words are in italics): 'Each party [to a mutually agreed solution] with respect to a matter raised under the dispute settlement provisions of the covered agreements shall notify the detailed terms of such solution to the DSB and relevant Councils and Committees. The notification shall be made in writing and submitted within ten days after reaching the solution. Any member may raise any point relating to the solution in the DSB and the relevant Councils and Committees.'

91 Voeten 2008. 
flows of the products concerned for all WTO members, we are able to demonstrate that privacy is associated with a higher likelihood of discriminatory settlements.

\section{REFERENCES}

Alschner, Wolfgang. 2012. Amicable Settlements of WTO Disputes: Recent Trends, New Concerns and Old Problems. World Trade Review 13 (1):65-102.

Bagwell, Kyle, and Robert. W. Staiger. 2004. Multilateral Trade Negotiations, Bilateral Opportunism and the Rules of GATT/WTO. Journal of International Economics 63 (1):1-29.

Bechtel, Michael, and Thomas Sattler. 2011. Trade and Litigate? The Effect of the WTO Dispute Settlement Body on Trade Relations.

Bown, Chad P. 2004. Trade Policy Under the GATT/WTO: Empirical Evidence of the Equal Treatment Rule. Canadian Journal of Economics/Revue Canadienne d'économique 37 (3):678-720.

— 2005. Participation in WTO Dispute Settlement: Complainants Interested Parties, and Free Riders. World Bank Economic Review 19:287-310.

- 2009. Self-Enforcing Trade: Developing Countries and WTO Dispute Settlement. Washington, DC: Brookings Institution Press.

Bown, Chad P., and Kara Reynolds. 2014. Trade Flows and Trade Disputes. World Bank Policy Research Working Paper WPS6979.

Busch, Marc L., and Eric Reinhardt. 2006. Three's a Crowd: Third Parties and WTO Dispute Settlement. World Politics 58:446-77.

Busch, Marc L., Eric Reinhardt, and Gregory Shaffer. 2009. Does Legal Capacity Matter? Explaining Dispute Initiation and Antidumping Actions in the WTO. World Trade Review 8:559-77.

Chaudoin, Stephen. 2014. Audience Features and the Strategic Timing of Trade Disputes. International Organization 68 (4):877-911.

Davey, William J., and Amelia Porges. 1998. Comments on Performance of the System I: Consultations and Deterrence. International Lawyer 32:695-707.

Davis, Christina. 2003. Food Fights Over Free Trade: How International Institutions and Issue Linkage Promote Agricultural Trade Liberalization. Princeton, NJ: Princeton University Press.

- 2011. Why Adjudicate? Enforcing Trade Rules. Princeton, NJ: Princeton University Press.

Fox, Justin. 2007. Government Transparency and Policymaking. Public Choice 131 (1):23-44.

Gilligan, Michael, Leslie Johns, and B. Peter Rosendorff. 2010. Strengthening International Courts and the Early Settlement of Disputes. Journal of Conflict Resolution 54:5-38.

Gowa, Joanne, and Soo Yeon Kim. 2005. An Exclusive Country Club. World Politics 57:453-78.

Horn, Henrik, and Petros C. Mavroidis. 2008. The WTO Dispute Settlement Data Set, 1995-2006. World Bank Data Archive. Available from http://go.worldbank.org/X5EZPHXJY0, accessed 5 December 2014.

Johns, Leslie, and Krzysztof J. Pelc. 2013. Fear of Crowds in WTO Disputes: Why Don't More Countries Participate? Available at SSRN 2292535.

Kahler, Miles. 2004. Defining Accountability Up: The Global Economic Multilaterals. Government and Opposition 39 (2):132-58.

Keohane, Robert, and Joseph Nye. 2001. Between Centralization and Fragmentation: The Club Model of Multilateral Cooperation and Problems of Democratic Legitimacy. Harvard Kennedy School Working Paper No. 01-004.

Kim, Soo Yeon. 2010. Power and the Governance of Global Trade: From the GATT to the WTO. Ithaca, NY: Cornell University Press.

Kurizaki, Shuhei. 2007. Efficient Secrecy: Public Versus Private Threats in Crisis Diplomacy. American Political Science Review 101 (3):543-58.

Leventoglu, Bahar, and Ahmer Tarar. 2005. Prenegotiation Public Commitment in Domestic and International Bargaining. American Political Science Review 99 (3):419-33.

Luban, David. 1994. Settlements and the Erosion of the Public Realm. Georgetown Law Journal 83: 2619-39. 
Maggi, Giovanni, and Andrís Rodríguez-Clare. 1998. The Value of Trade Agreements in the Presence of Political Pressures. Journal of Political Economy 106 (3):574-601.

Maggi, Giovanni, and Robert W. Staiger. 2008. On the Role and Design of Dispute Settlement Procedures in International Trade Agreements. Cambridge, MA: National Bureau of Economic Research.

Mansfield, Edward D., Helen V. Milner, and B. Peter Rosendorff. 2002. Why Democracies Cooperate More: Electoral Control and International Trade Agreements. International Organization 56: 477-514.

Martin, Lisa L., and Beth A. Simmons. 1998. Theories and Empirical Studies of International Institutions. International Organization 52 (4):729-57.

McCubbins, Matthew D., and Thomas Schwartz. 1984. Congressional Oversight Overlooked: Police Patrols Versus Fire Alarms. American Journal of Political Science 28 (1):165-79.

McGillivray, Fiona. 2000. Democratizing the World Trade Organization, Hoover Press. Stanford, CA: Stanford University Press.

Menkel-Meadow, Carrie. 1995. Whose Dispute Is it Anyway: A Philosophical and Democratic Defense of Settlement (In Some Cases). Georgetown Law Journal 83:2663-96.

Moravcsik, Andrew. 2004. Is there a Democratic Deficit in World Politics? A Framework for Analysis. Government and Opposition 39 (2):336-63.

Nakagawa, Junji. 2007. No More Negotiated Deals? Settlement of Trade and Investment Disputes in East Asia. Journal of International Economic Law 10 (4):837-67.

Schmitter, Philippe C. 2003. Democracy in Europe and Europe's Democratization. Journal of Democracy 14 (4):71-85.

Sevilla, Christina R. 1997. A Political Economy Model of GATT/WTO Trade Complaints. Cambridge, MA: Harvard Law School.

Staiger, Robert W., and Guido Tabellini. 1987. Discretionary Trade Policy and Excessive Protection. American Economic Review 77 (5):823-37.

1999. Do GATT Rules Help Governments Make Domestic Commitments? Economics and Politics 11 (2):109-44.

Stasavage, David. 2004a. Open-Door or Closed-Door? Transparency in Domestic and International Bargaining. International Organization 58:667-703.

—. 2004b. Public Versus Private Deliberation in a Representative Democracy. Unpublished manuscript, London School of Economics.

Steinberg, Richard H. 2002. In the Shadow of Law or Power? Consensus-Based Bargaining and Outcomes in the GATT/WTO. International Organization 56 (2):339-74.

Subramanian, Arvind, and Shang-Jin Wei. 2007. The WTO Promotes Trade, Strongly but Unevenly. Journal of International Economics 72 (1):151-75.

Vaubel, Roland. 1986. A Public Choice Approach to International Organization. Public Choice 51 (1): 39-57.

Voeten, Erik. 2008. The Impartiality of International Judges: Evidence from the European Court of Human Rights. American Political Science Review 102:417-33.

Vreeland, James Raymond. 2003. The IMF and Economic Development. New York: Cambridge University Press.

World Trade Organization. 2004. A Handbook on the WTO Dispute Settlement System: A WTO Secretariat Publication. WTO Internal Only Series. Cambridge: Cambridge University Press. 